\title{
Mixed-cropping systems of different rice cultivars have grain yield and quality advantages over mono-cropping \\ systems
}

Meijuan $\mathrm{Li}^{1}$, Jiaen Zhang ${ }^{1,2,3, *}$, Shiwei Liu ${ }^{1}$, Umair Ashraf ${ }^{4,5}$, Shuqing Qiu ${ }^{1}$

1 Department of Ecology, College of Natural Resources and Environment, South China Agricultural University, Wushan Road, Tianhe District, Guangzhou 510642, P.R. China

2 Guangdong Provincial Engineering Technology Research Centre of Modern Eco-agriculture and Circular Agriculture, Guangzhou 510642, P.R. China

${ }^{3}$ Key Laboratory of Agro-Environment in the Tropics, Ministry of Agriculture, Guangzhou 510642, P.R. China

${ }^{4}$ Department of Agronomy, University of Agriculture, Faisalabad, 38040 Pakistan

${ }^{5}$ Department of Crop Science and Technology, College of Agriculture, South China Agricultural University, Guangzhou 510642, P.R. China

\section{* Corresponding author}

E-mail:jeanzh@scau.edu.cn 


\section{Abstract}

Mixed-cropping system is a centuries-old cropping technique that is still widely practiced in the farmers' field over the globe. Increased plant diversity enhances farmland biodiversity, which would improve grain yield and quality; however, the impacts of growing different rice cultivars simultaneously were rarely investigated. In present study, five popular rice cultivars were selected and ten mixture combinations were made according to the growth period, plant height, grain yield and quality, and pest and disease resistance. Seedlings of the five cultivars and ten mixture combinations (mixed-sowing of the seeds in an equal ratio, then mixed-transplanting and finally mixed-harvesting) were grown in plastic pots under greenhouse during the early and late growing seasons in 2016. Results showed that, compared with the corresponding mono-cropping systems, almost all combinations of the mixed-cropping systems have advantages in yield related traits and grain quality. Compared with the mono-cropping systems in the early and late growing seasons in 2016, mixed-cropping systems increased the number of spikelets per panicle, seed-setting rate, and grain weight per pot and harvest index by $19.52 \%$ and $5.77 \%$, $8.53 \%$ and $4.41 \%, 8.31 \%$ and $4.61 \%$, and $10.26 \%$ and $6.98 \%$, respectively (paired t-test). In addition, mixed-cropping systems reduced chalky rice rate and chalkiness degree by $33.12 \%$ and $43.42 \%$ and by $30.11 \%$ and $48.13 \%$ in the early and late growing seasons, respectively (paired t-test). These results may be due to enhanced SPAD indexes and photosynthetic rates at physiology maturity in mixed-cropping systems. In general, it was found that mixed-cropping with different rice cultivars have potential for increasing grain yield and improving grain quality. 


\section{Introduction}

Rice (Oryza sativa L.) is the primary food source for more than one-third of the world's population [1]. The socio-economic and climatic factors are negatively affecting rice production worldwide [2-4]. Recently, efforts have been made to modernize the rice production systems by replacing traditional farming systems with improved production practices and agricultural mechanization [5]. The traditional farming systems at small and large scale have greatly been replaced with intensified and highly mechanized mono-culture based cropping systems [6-8]. These production systems are largely rely on chemical fertilizers and pesticides which may cause significant surface and groundwater contamination and potential health risks $[9,10]$. The intensive cropping increases the chances of soil erosion, greenhouse gas emission, pest resistance, and the loss of biodiversity. Hence, sustainable crop production systems are essential over the long term to meet the consumers' demand for better-quality food products $[11,12]$.

Multi-cropping, refers to as 'intercropping' or 'mixed-cropping', is the growing multiple crop species/cultivars simultaneously in the same field for a significant part of their life cycle $[6,13]$. Numerous studies have reported how ecological processes result in yield advantages in mixed-cropping systems compared to those in mono-cropping systems. For example, studies on grasslands have shown that multi-species produced 15\% higher yields than mono-crops [14]. Mixed-cropping has also been shown to produce 1.7 times more biomass than single species mono-cropping and to be $79 \%$ more productive than mono-cropping system [15]. In addition to yield, there are many other benefits of multiple-cropping such as enhanced soil fertility by intercropping with nitrogen-fixers [16], increased resilience against pests and diseases [17], and increased abiotic stress tolerance have also been previously reported $[18,19]$. These effects are attributed to higher levels of genetic diversity within those systems $[6,7,16,20,21]$.

Furthermore, mixed-cropping systems are mainly used in tropical, small-scale subsistence farming [6], however, it may have some practical issues, such as drilling, 
sowing, spraying and harvesting practices etc. Differing growth cycles and requirements for nutrients and pesticides make it difficult for growers to adapt new systems to manage and harvest mixed crops $[6,21,22]$.

However, it is easy to operate the mixed-cropping systems when several cultivars belong to the same species(eco-types), are mixed and seeded in the same field. Meanwhile, mixed-cropping systems may have higher resistance to diseases or pests, higher production, better grain quality, and may allow the situ production of formula rice (products with different rice varieties) easily. Till now, no work has been done to examine the effects of cultivating different rice genotypes in different combination on grain yield and quality of rice. Therefore, in this study, the seeds of different rice cultivars (possess different growth periods, plant heights, disease and pest resistance, grain yield and quality), were mixed and planted. It was hypothesized that a mixed-cropping system with different rice cultivars would have advantages over mono-cropping systems for a series of traits related to grain production and quality.

\section{Materials and Methods}

Experiments were conducted in 2016 during the early (March-July) and late growing seasons (August-November) of rice in the greenhouse at the Eco-Farm in the campus of South China Agricultural University $\left(113^{\circ} 21^{\prime} \mathrm{E}, 23^{\circ} 09^{\prime} \mathrm{N}\right)$, Guangzhou, China. This region has a humid subtropical monsoonal climate characterized by warm winter and hot summers with an average annual temperature between $20^{\circ} \mathrm{C}$ and $22^{\circ} \mathrm{C}$.

\section{Experimental details}

Five conventional indica rice cultivars of which four i.e., Yuenongsimiao, Yuxiangyouzhan, Huangguangyouzhan and Huanghuazhan were obtained from the Rice Research Institute of the Guangdong Academy of Agricultural Sciences and one i.e., Huahang 31 from the National Engineering Research Centre of Plant Breeding at South China Agricultural University (named as A, B, C, D and E, respectively) were used as plant material. Out of 26 possible 1:1 mixture combinations of five genotypes, we selected ten combinations i.e., $\mathrm{BC}, \mathrm{BE}, \mathrm{AB}, \mathrm{BCE}, \mathrm{ACD}, \mathrm{BDE}, \mathrm{ABD}, \mathrm{BCDE}$, 
$\mathrm{ABDE}$ and $\mathrm{ABCDE}$ according to the growth period, plant height, grain yield, grain qualities, and resistance to diseases and pests of the five cultivars. The seed mixtures (mixing the seeds in an equal ratio) were sown in PVC trays and then the 35-day-old seedlings were transferred to the soil containing plastic pots $(60 \times 45 \times 29 \mathrm{~cm})$ filled with $30 \mathrm{~kg}$ of soil from paddy fields and grown in the greenhouse during the early and late growing seasons in 2016. The five cultivars were also grown in pure stands in mono-cropping systems as the corresponding controls. The experimental soil was sandy loam containing $25.44 \mathrm{~g} \mathrm{~kg}^{-1}$ organic matter, $1.14 \mathrm{~g} \mathrm{~kg}^{-1}$ total nitrogen, $0.84 \mathrm{~g}$ $\mathrm{kg}^{-1}$ total phosphorous, $22.36 \mathrm{~g} \mathrm{~kg}^{-1}$ total potassium and had a $\mathrm{pH}$ of 5.98. Before transplanting, $100 \mathrm{~g}$ of organic fertilizer $\left(\mathrm{N}, \mathrm{P}_{2} \mathrm{O}_{5}, \mathrm{~K}_{2} \mathrm{O} \geq 6 \%\right.$, organic matter $\left.\geq 46 \%\right)$ was applied per pot. There were 3 replications for 5 cultivars and 10 mixtures whilst 6 hills (6 seedlings for each hill) with a planting space of $20 \times 15 \mathrm{~cm}$ for each pot were maintained. A water layer of about $2-3 \mathrm{~cm}$ was maintained for the whole growth period.

\section{Trait measurements}

The photosynthetic rate (Pn), relative chlorophyll contents (SPAD) and total aboveground dry weight (DW) were measured at physiological maturity. The maximum $\mathrm{CO}_{2}$ assimilation rate per unit area $\left(\mathrm{Pn} ; \mu \mathrm{mol} \mathrm{m} \mathrm{m}^{-2} \mathrm{~s}^{-1}\right)$ was measured between 9:00 and 11:00 am using a Li-6400 portable photosynthetic system (Li-6400, Li-Cor, USA). Based on preliminary trials, the photosynthetic photon flux density was set at $1000 \mu \mathrm{mol} \mathrm{m} \mathrm{m}^{-2} \mathrm{~s}^{-1}$ for all rice cultivars. Both of the ambient $\mathrm{CO}_{2}$ and air temperature were maintained at $390 \mu \mathrm{mol} \mathrm{mol}^{-1}$ and $28^{\circ} \mathrm{C}$, respectively. Relative chlorophyll contents of flag leaf were estimated with a SPAD meter (SPAD-502, Osaka, Japan). The plants were kept in oven at $80^{\circ} \mathrm{C}$ till constant weight for determination of dry biomass.

Grain yield and its components were measured according to the methods described by Peng et al. (2004) [23]. At maturity stage, plants were sampled from the plastic pots and the panicles were cut off into straw and panicle individuals. All spikelets were separated from the rachis (by manual threshing), and divided into filled and 
unfilled rice by the Seeds Winnowing machine (CFY-II, $3.8 \mathrm{~m}^{3} \mathrm{~min}$, max air pressure 1300 pa, Hangzhou, China). The total number of spikelets, filled and unfilled, all of the half-filled spikelets were classifically taken and averaged. The number of spikelets per panicle, grain-filling percentage $(100 \times$ the number of filled spikelets / the total number of spikelets), and 1000-grain-weight were also calculated from sampled plants and averaged. Grain yield was recorded from each pot and the grain moisture was reduced to $14 \%$ by sun drying before being weighed.

Representative samples of about $250 \mathrm{~g}$ of filled grains collected from each mono-cropping and mixed-cropping treatment were analyzed for grain quality. After dehulling and polishing rough rice, head rice (with length $\geq 3 / 4$ of its total grain length) was weighed and used to calculate head rice yield. Physical traits such as chalky rice rate, chalkiness degree, grain length and width were scanned by a Plant Mirror Image Analysis (MICROTEK ScanMaker i800plus, Shanghai, China), and the image was processed with SC-E software (Hangzhou Wanshen Detection Technology Co., Ltd., Hangzhou, China). The standard iodine colorimetric method described in GB/T 15683-2008 (National Standard of the People's Republic of China, 2008) was used to measure amylose content and the Coomassie Brilliant Blue Staining method was used to measure the grain soluble protein contents.

\section{Data analysis}

The independent t-test was performed to evaluate the differences in traits between the mono-cropping and mixed-cropping treatments. For example, the data from A and B mono-cropping systems were pooled, and then compared with these data from $\mathrm{AB}$ mixed-cropping system. To assess the total effect of mixed-cropping, a paired analysis (t-test when data met assumptions of normality) and wilcoxon signed-rank test (when data did not meet the assumptions of normality) was carried out for all combinations and their mid-component average (the average of mixture components grown as mono-cropping). All the analyses were conducted in $\mathrm{R} 3.20$ ( $\mathrm{R}$ Foundation for Statistical Computing). 


\section{Results}

\section{Grain yield and its components}

There were some significant differences in both yield and yield components between the mono-cropping and mixed-cropping systems for both early and late growing season in 2016 (Paired t-test, Tables 1 and 2). The spikelet per panicle, seed-setting rate, and grain weight per pot and harvest index were $19.52 \%$ and $5.77 \%, 8.53 \%$ and $4.41 \%, 8.31 \%$ and $4.61 \%$, and $10.26 \%$ and $6.98 \%$ higher in the mixed-cropping systems than those in the mono-cropping systems in the early and late growing seasons, respectively. In the early growing season, the mixed-cropping system improved the number of spikelets per panicle and seed-setting rate, compared with mono-cropping system, but statistically non-significant $(P>0.05)$ for some cases (Independent t-test). The grain weight per pot, only in the mixed-cropping systems of combinations of $\mathrm{BC}, \mathrm{ACD}, \mathrm{BDE}$ and $\mathrm{ABDE}$, was significantly higher than that in the corresponding mono-cropping systems in the early growing season. Moreover, the grain weight was almost higher in the mixed-cropping systems in the early growing season and in most mixed-cropping combinations (except BE, $\mathrm{ABD}$ and $\mathrm{ABCDE}$ ) in the late growing season, compared with the mono-cropping system. However, enhanced 1000-grain-weight was found only in some mixed-cropping systems in both the early and late growing seasons.

Table 1. Differences of yield and its components between mono-cropping and corresponding mixed-cropping systems with several cultivars in the early growing season of 2016.

Note: Mean values ( \pm SEs) of traits measured for mono-cropping systems and mixed-cropping systems. For each pair of combination we performed an independent t-test, and mean differences between mono-cropping systems and mixed-cropping systems were tested with paired t-tests. Mono, mono-cropping system; mix, mixed-cropping system. $* P<0.05 ; * * P<0.01$.

Table 2. Differences of yield and its components between mono-cropping and 
corresponding mixed-cropping systems with several cultivars in the late growing season of 2016.

Note: Table explanations are provided in Table 1.

\section{Grain quality}

For grain quality, chalky rice rate and chalkiness degree were significantly $(P<0.05)$ decreased in the mixed-cropping systems in the early growing season, while other traits were not significantly different from those in the mono-cropping systems. Further, the mixed-cropping systems reduced the chalky rice rate and chalkiness degree by $33.12 \%$ and $43.42 \%$, and $30.11 \%$ and $48.13 \%$ in the early and late growing seasons, respectively (Paired t-test, Tables 3 and 4). In the early season, only for several cases, grain milling and appearance, cooking and nutritional qualities of the mixed-cropping systems were significantly $(P<0.05)$ higher than those of the mono-cropping systems, whereas significant differences were found between mono-cropping and mixed-cropping systems in the late growing season (Independent t-test).

Table 3 Differences of grain quality between mono-cropping and corresponding mixed-cropping systems with several cultivars in the early growing season of 2016.

Note: Table explanations are provided in Table 1.

Table 4 Differences of grain quality between mono-cropping and corresponding mixed-cropping systems with several cultivars in the late growing season of 2016. Note: Table explanations are provided in Table 1.

\section{Photosynthetic rate, SPAD index and Total Aboveground}

\section{Dry Weight}

In both growing seasons, the photosynthetic rate for all mixed-cropping treatments was higher than that in the mono-cropping treatments, but non-significant for some cases at the maturity stage (Independent t-test, Figs 1a-b). Similar patterns were found 
219 for SPAD index and total aboveground dry weight (Independent t-test, Figs 1c-f).

220 Compared with the mono-cropping systems, SPAD index and Pn of the mixed-cropping systems were significantly higher in the early and late growing seasons (pair t-test, Fig. 1). Total aboveground dry weight was also significantly higher for the mixed-cropping treatments in the early growing season but not in the late growing season (pair t-test, Fig. 1). These results indicated that photosynthetic related traits (such as SPAD index and photosynthetic rate) were increased in the mixed-cropping systems, which may in turn enhance aboveground dry weight.

Fig. 1 Differences between mono-cropping and corresponding mixed-cropping systems with several cultivars at the maturity stage in the early and late growing season of 2016: (a-b) SPAD index, (c-d) photosynthetic rate $\left(P_{n}\right)$, and (e-f) total aboveground dry weight. Insets: differences in trait values between mixed-cropping systems and mono-cropping systems (paired t-test). White columns indicate mono-cropping systems and grey columns indicate corresponding mixed-cropping systems. * and ${ }^{*}$ represent significance differences at $P<0.05$ and $P<0.01$ levels, respectively; ns indicates non-significant.

\section{Correlations analyses}

Pn was significantly $(P<0.05)$ and positively correlated with DW $(\mathrm{r}=0.67$ for the early growing season), seed-setting rate $(\mathrm{r}=0.59$ and $\mathrm{r}=0.74)$, grain weight per pot $(r=0.53$ and $r=0.60)$ and harvest index $(r=0.77$ and $r=0.63)$ for the early and late growing seasons, respectively (Table 5). A similar pattern was observed for the SPAD index. The results indicated that higher Pn and SPAD index may lead to higher grain yield and yield related traits.

Significantly positive correlations between SPAD index and milled rice rate, whole milled rice rate and protein content were noticed, whilst negative correlations between SPAD index and chalky rice rate were found in the early season (Table 5). Pn was positively correlated with brown rice rate, whole milled rice rate and protein content, whilst negatively correlated with chalky rice rate, chalkiness degree and brown rice rate in the early season. Similar patterns were found in the late season. 
Table 5 Correlations analysis between photosynthetic parameters, SPAD index at the maturity stage and yield related traits and grain quality in the early and late growing seasons in 2016.

Note: *and $* *$ represent significance at $P<0.05$ and 0.01 levels, respectively.

\section{Discussion}

Scientists have different opinions regarding mixed-cropping owing to pre-sowing mixing of seeds of different cultivars/genotypes. For instance, some have found this practice was superior to the mono-cropping [24-27], whilst some regarded it as inferior to the mono-cropping regarding yield benefits [28], and others found it depended on the combinations of varieties [29].

Our results showed that compared with mono-cropping systems, mixed-cropping systems indeed have advantages in yield related traits e.g., the number of spikelets per panicle, seed-setting rate, grain weight and harvest index, as well as grain quality traits, e.g. chalky rice rate and chalkiness degree. Positive effects of mixed-cropping systems on plant production generally rely on functional differences between cultivars $[30,31]$. For example, mixing of seeds of those cultivars having exactly the same functional characteristics would not lead to any additive effect in yield and/or overall production. Previously, it was reported that sometimes seed mixture of different genotypes could lead to yield benefits over individual potential of one cultivar as mono-cropping system. For example, Dubin and Wolfe (1994) [32] reported a 2\% increase in grain yield in three-way wheat (Triticum aestivum L.) variety mixtures compared with those in pure lines. Helland and Holland (2001) [25] also found an increase of 3\% in three oat (Avena sativa L.) varieties when grown in mixture rather than mono-crop. Likewise, Gallandt et al. (2001) [33] demonstrated that winter wheat mixtures of two cultivars resulted in $1.5 \%$ yield advantage over pure lines, whereas Sarandon and Sarandon (1995) [34] reported that two-way bread wheat mixtures increased the aboveground dry weight by $8 \%$ as compared with pure lines.

Our experimental results showed that the Pn, SPAD index and total aboveground dry weight of the mixed-cropping systems were higher than the component cultivars 
277 that were grown in pure lines (Fig. 1). Enhanced Pn and SPAD index might lead to the improved performance of rice mixtures. Chlorophylls contents (expressed as SPAD index), is one of the most important factors associated with photosynthetic rate, as well as crop biomass and economic yield in rice [35]. Enhanced photosynthetic rate even at the single-leaf level was recently been found to be a significant contributor in improving crop productivity [36,37]. Furthermore, positive correlations between the photosynthetic rate, SPAD index, total aboveground dry weight and the grain weight per pot in the early and late growing seasons were also observed at the maturity. These results in our study with a real mixed-cropping (growing two or more rice crops simultaneously without definite row arrangement on the same paddy field, i.e. with real mixed-sowing of the seeds in an equal ratio, then mixed-transplanting and finally mixed-harvesting) further corroborate previous study findings which indicate that 'mixed-cropping systems' (growing different crop cultivars with definite row arrangements) and 'intercropping systems' (growing two or more crops simultaneously with definite row arrangement on the same piece of land) improved the rice stand establishment and resource use efficiency than mono-cropping systems $[7,20,38]$. In addition, mixed-cropping systems may have benefit in exploiting available resources in a better way than mono-cropping systems and would thus lead to improved grain yield and harvest index [27,29].

Grain quality includes grain appearance and milling, eating, cooking, and nutritional qualities. Genetic, environmental and crop management factors generally affect the grain quality of rice. Our study showed that the chalky rice rate and chalkiness degree of mixed-cropping systems were decreased compared to that of the mono-cropping systems (Tables 3 and 4). Furthermore, negative correlations among SPAD index, Pn and total aboveground dry weight as well as chalky rice rate with chalkiness degree in both growing seasons were recorded. Increased Pn, SPAD index and the total aboveground dry weight observed in the mixed-cropping systems at maturity (Pair t-test, Fig. 1) may in turn contribute to the lower chalky rice rate and increase the occurrence of chalky grains $[39,40]$, while increased Pn of rice leaves 
resulting in the reduction of chalky rice rate and chalkiness degree.

Furthermore, no significant differences for grain quality traits i.e., brown rice rate, milled rice rate, whole milled rice rate, amylose rate, protein content, or length/width were found between mixed-cropping systems and mono-cropping systems, and also inconsistent for both the growing seasons(Tables 3 and 4). These inconsistent quality parameters during both the growing seasons were possibly related to environmental differences between the early and late growing seasons $[41,42]$. Effects of cultivating varieties from the same species with mixed seedling, transplanting and harvesting on grain amylose rate, protein content, and length/width are still poorly understood. Previously, in a study focused on a barley-oats mixed system, Jokinen (1991) [43] found that protein content was varied substantially in mixed cropping system rather in mono-cropping system of individual crops.

Overall, the differential crop responses for both mixed-cropping and mono-cropping systems are possibly due to genetic differences among rice cultivars. However, we acknowledge some uncertainties and limitations in our data. For example, firstly, we conducted a pot experiment in this study, whereas pot size, volume, shape, material and even color may influence plant growth [44]. Secondly, we planted rice in a well-controlled greenhouse, and no pests and diseases were detected in both growing seasons, however, the disease resistance of mixed-cropping systems may have more advantages in the field. For example, the effect of mixed cropping systems for pests in organic oilseed crops were evaluated, and the result showed that the infestation by insect pests was directly reduced in mixtures with winter rape (Brassica napus) hints and cereals or legumes [45]. Thirdly, with meticulous management and monitoring, there were few weeds in this pot experiment. Indeed, there were some biological effects on weeds-suppressing in mixture with organic linseed (Linum usitatissivum) and wheat in the field [45]. Therefore, a field based evaluation of different rice cultivars under mixed cropping system is needed in future.

\section{Conclusions}


336 In the present study, results showed that the mixed-cropping systems with real mixed-

337 sowing, mixed-transplanting and finally mixed-harvesting have advantages in yield

338 related traits and grain quality compared with the corresponding mono-cropping

339 systems. Relative to the mono-cropping systems, mixed-cropping systems increased

340 the number of spikelets per panicle, seed-setting rate, and grain weight per pot and

341 harvest index. Additionally, mixed-cropping systems reduced chalky rice rate and

342 chalkiness degree. Hence, mixed-cropping system with different rice cultivars would

343 be more productive with higher quality than the mono-cropping systems.

344 Acknowledgements

345 We acknowledge the funding provided by the Science and Technology Project of

346 Guangdong Province (2015B090903077, 2016A020210094), the Science and

347 Technology Project of Guangzhou (201604020062), the Innovation Team

348 Construction Project of Modern Agricultural Industry Technology System of

349 Guangdong Province (2016LM1100), the Overseas Joint Doctoral Training Program

350 of South China Agricultural University (2018LHPY010). 


\section{Supporting information}

352 S1 Table S1 Traits of the five varieties that accessed from the China Rice Data Center.

353 Note: Data from: http://www.ricedata.cn/ 


\section{References}

355 1. Thai PPD, Hiroki K, Ryo I, Takashige I. Estimation of the outcrossing rate for annual Asian wild rice under field conditions. Breeding Science. 2012; 3: 256-262.

2. Khush GS. What it will take to Feed 5.0 Billion Rice consumers in 2030. Plant Molecular Biology. 2005; 1: 1-6.

3. Qian Q, Guo L, Smith SM, Li J. Breeding high-yield superior quality hybrid super rice by rational design. National Science Review. 2016; 3: 283-294.

4. Ray DK, Ramankutty N, Mueller ND, West PC, Foley JA. Recent patterns of crop yield growth and stagnation. Nature Communications, 2012; 3: 1293.

5. Frison EA. From Uniformity to Diversity: A paradigm shift from industrial agriculture to diversified agro-ecological systems Enter title. International Panel of Experts on Sustainable Food Systems (IPES-Food). http://www.ipes-food.org; 2016.

6. Lithourgidis AS, Dordas CA, Damalas CA, Vlachostergios DN. Annual intercrops: an alternative pathway for sustainable agriculture. Australian Journal of Crop Science. 2011; 5(4): 396-410.

7. Malézieux E, Crozat Y, Dupraz C, Laurans M, Makowski D, Ozier-Lafontaine, et al. Mixing plant species in cropping systems: concepts, tools and models. A review. Agronomy for Sustainable Development. 2009; 29(1): 43-62.

8. Whitmore AP, SchröDer JJ. Intercropping reduces nitrate leaching from under field crops without loss of yield: A modelling study. European Journal of Agronomy. 2007; 27(1): $81-88$

9. Strand JF. Some agrometeorological aspects of pest and disease management for the $21 \mathrm{st}$ century. Agricultural \& Forest Meteorology. 2000; 103(1): 73-82.

10. Guziejewski D, Skrzypek S, Ciesielski W. Square wave adsorptive stripping voltammetric 
12. Popp J, Pető K, Nagy J. Pesticide productivity and food security. A review. Agronomy for Sustainable Development. 2013; 33(1): 243-255.

13. Vandermeer J, Mvan N, Anderson J, Ong C, Perfecto I. Global change and multi-species agro-ecosystems: concepts and issues. Agriculture Ecosystems \& Environment. 1998; 67(1): $1-22$.

14. Prieto I, Violle C, Barre P, Durand JL, Ghesquiere M, Litrico I. Complementary effects of species and genetic diversity on productivity and stability of sown grasslands. Nature Plants. 2015; 1(4): 15033 .

15. Cardinale BJ, Wright JP, Cadotte MW, Carroll IT, Hector A, Srivastava DS, et al. Impacts of plant diversity on biomass production increase through time because of species complementarity. Proceedings of the National Academy of Sciences of the United States of America. 2007; 104(46): 18123-18128.

16. Hauggaard-Nielsen H, Jensen ES. Facilitative Root Interactions in Intercrops. Plant and Soil. 2005; 274(1-2): 237-250.

17. Trenbath BR. Intercropping for the management of pests and diseases. Field Crops Research. 1993; 34(3): 381-405.

18. Eisenhauer N. Aboveground-belowground interactions as a source of complementarity effects in biodiversity experiments. Plant and Soil. 2012; 351(1-2): 1-22.

19. George SJ, Harper RJ, Hobbs RJ, Tibbett M, Audet P, Mulligan D, et al. A sustainable agricultural landscape for Australia: a review of interlacing carbon sequestration, biodiversity and salinity management in agroforestry systems. Agriculture Ecosystems \& Environment. 2012; 163(12): 28-36.

20. Zhu YY, Chen HR, Fan JH, Wang YY, Yan L, Chen JB, et al. Genetic diversity and disease control in rice. Nature. 2000; 406(6797): 718-722.

21. Tosti G, Guiducci M. Durum wheat-fava bean temporary intercropping: Effects on nitrogen supply and wheat quality. European Journal of Agronomy. 2010; 33(3): 157-165.

22. Anil L, Park J, Phipps RH, Miller FA. Temperate intercropping of cereals for forage: a review of the potential for growth and utilization with particular reference to the UK. Grass \& Forage Science. 2010; 53(4): 301-317.

23. Peng S, Huang J, Sheehy JE, Laza RC, Visperas RM, Zhong X, et al. Rice yields decline with 
higher night temperature from global warming. Proceedings of the National Academy of Sciences of the United States of America. 2004; 101(27): 9971-9975.

24. Cheema NM, Chowdhry MA, Gliddon CJ. Varietal blends and their performance in spring wheat. Pakistan Journal of Agricultural Research. 1988; 2(9), 141-146.

25. Helland SJ, Holland JB. Blend response and stability and cultivar blending ability in oat. Cropence. 2001; 41(6): 1689-1696.

26. Pridham JC, Entz MH, Martin RC, Hucl PJ. Weed, disease and grain yield effects of cultivar mixtures in organically managed spring wheat. Canadian Journal of Plant Science. 2007; 87(4): 855-859.

27. Kiær LP, Skovgaard IM, Østergård H. Grain yield increase in cereal variety mixtures: A meta-analysis of field trials. Field Crops Research. 2009; 114(3): 361-373.

28. Juskiw PE, Helm JHBurnett PA. Three-component barley mixtures: Ratio effects in replacement series. Canadian Journal of Plant Science. 2001; 81(4): 651-656.

29. Darras S, Mckenzieross RH, Olsonmark MA, Willenborgchristian CJ. Influence of genotypic mixtures on field pea yield and competitive ability. Canadian Journal of Plant Science. 2014; 95(2): 315-324.

30. Diaz S, Cabido M. Vive la difference: plant functional diversity matters to ecosystem

31. Tilman D, Wedin D, Knops J. Productivity and sustainability influenced by biodiversity in processes. Trends in Ecology \& Evolution. 2001; 16(11): 646-655. grassland ecosystems. Nature. 1996; 379(6567): 718-720.

32. Dubin HJ, Wolfe MS. Comparative behavior of three wheat cultivars and their mixture in India, Nepal and Pakistan. Field Crops Research. 1994; 39(2-3): 71-83.

33. Gallandt ER, Dofing SM, Reisenauer PE, Donaldson E. Diallel Analysis of Cultivar Mixtures in Winter Wheat. Crop Science. 2001; 41(3): 792-796.

34. Sarandon SJ, Sarandon R. Mixture of Cultivars: Pilot Field Trial of an Ecological Alternative to Improve Production or Quality of Wheat (Triticum aestivum). Journal of Applied Ecology. 1995; 32(2): 288-294.

35. Liu J, Wang J, Yao X, Zhang Y, Li J, Wang X, et al. Characterization and fine mapping of thermo-sensitive chlorophyll deficit mutant1 in rice (Oryza sativa L.). Breeding Science. 2015; 65(2): 161-169. 
36. Yamori W, Kondo E, Sugiura D, Terashima I, Suzuki Y, Makino A. Enhanced leaf photosynthetic as a target to increase grain yield: Insights from transgenic rice lines with variable Rieske FeS protein content in the Cytochrome b6/f complex. Plant Cell \& Environment. 2016; 39(1): 80-87.

37. Zhu XG, Song Q, Ort DR. Elements of a dynamic systems model of canopy photosynthetic. Current Opinion in Plant Biology. 2012; 15(3): 237-244.

38. Gurr GM, Wratten SD, Luna JM. Multi-function agricultural biodiversity: pest management and other benefits. Basic \& Applied Ecology. 2003; 4(2): 107-116.

39. Hayashi M, Hayashi T, Kuno C, Tani T, Endo I, Higashino A, et al. Enhanced Nitrogen Uptake and Photosynthetic of Rice Grown with Deep and Permanent Irrigation Method: Possible Mechanism for Chalky Grain Reduction. Plant Production Science. 2013; 16(4): 309-316.

40. Tabata M, Iida Y, Okuno K. Abnormal Grain Quality Caused by Partial Excision of Root System in Rice. Japanese Journal of Crop Science. 2008; 77: 198-203.

41. Rehmani MIA, Wei G, Hussain N, Ding C, Li G, Liu Z, et al. Yield and quality responses of two indica rice hybrids to post-anthesis asymmetric day and night open-field warming in lower reaches of Yangtze River delta. Field Crops Research. 2014; 156(2): 231-241.

42. Shi W, Yin X, Struik PC, Xie F, Schmidt RC, Jagadish KSV. Grain yield and quality responses of tropical hybrid rice to high night-time temperature. Field Crops Research, 2016; 190: $18-25$.

43. Jokinen K. Competition and yield advantage in barley-barley and barley-oats mixtures [in Finland]. Journal of Agricultural Science in Finland.1991.

44. Poorter H, Van Dusschoten D, Postma JA. Pot size matters: a meta-analysis of the effects of rooting volume on plant growth. Functional Plant Biology. 2012; 39(10-11): 839-850.

45. Paulsen HM, Schochow M, Ulber B, Kühne S, Rahmann G. Mixed cropping systems for biological control of weeds and pests in organic oilseed crops. Aspects of Applied Biology. 2006; 79: 215-220. 
Table 1

\begin{tabular}{|c|c|c|c|c|c|}
\hline Treatments & $\begin{array}{l}\text { The number of } \\
\text { spikelet } \\
\text { per panicle }\end{array}$ & $\begin{array}{l}\text { Seed-setting } \\
\text { rate }(\%)\end{array}$ & $\begin{array}{l}\text { Grain weight (g } \\
\text { per pot) }\end{array}$ & $\begin{array}{l}\text { 1000-grain } \\
\text {-weight }(\mathrm{g})\end{array}$ & Harvest index \\
\hline \multicolumn{6}{|l|}{ Independent $t$-test } \\
\hline Mono-AB & $46.05 \pm 5.72$ & $63.83 \pm 1.88$ & $52.13 \pm 3.63$ & $20.11 \pm 0.43$ & $0.39 \pm 0.02$ \\
\hline Mixed-AB & $56.05 \pm 1.25$ & $70.14 \pm 0.29$ & $53.76 \pm 3.41$ & $18.61 \pm 1.12$ & $0.45 \pm 0.00$ \\
\hline Mono-BC & $50.20 \pm 7.39$ & $62.50 \pm 1.44$ & $51.64 \pm 3.30$ & $19.37 \pm 0.13$ & $0.42 \pm 0.01$ \\
\hline Mixed-BC & $60.46 \pm 2.53$ & $68.09 \pm 0.90^{*}$ & $61.09 \pm 1.92$ & $20.70 \pm 0.45^{* *}$ & $0.47 \pm 0.02 *$ \\
\hline Mono-BE & $53.11 \pm 8.78$ & $65.79 \pm 2.76$ & $49.65 \pm 2.41$ & $18.86 \pm 0.36$ & $0.38 \pm 0.02$ \\
\hline Mixed-BE & $58.73 \pm 0.69$ & $68.66 \pm 2.32$ & $49.63 \pm 1.10$ & $17.80 \pm 1.01$ & $0.37 \pm 0.02$ \\
\hline Mono-ABD & $43.09 \pm 4.01$ & $66.48 \pm 1.81$ & $52.97 \pm 2.38$ & $20.39 \pm 0.32$ & $0.40 \pm 0.01$ \\
\hline Mixed-ABD & $66.24 \pm 1.67 * *$ & $68.92 \pm 1.33$ & $56.89 \pm 1.95$ & $18.91 \pm 1.02$ & $0.39 \pm 0.01$ \\
\hline Mono-ACD & $53.75 \pm 4.41$ & $68.34 \pm 1.09$ & $57.82 \pm 1.07$ & $20.38 \pm 0.32$ & $0.39 \pm 0.01$ \\
\hline Mixed-ACD & $64.21 \pm 1.79$ & $77.63 \pm 1.84 * *$ & $62.47 \pm 0.61^{*}$ & $23.25 \pm 0.61 * *$ & $0.46 \pm 0.01 *$ \\
\hline Mono-BCE & $57.46 \pm 6.08$ & $65.62 \pm 1.84$ & $52.74 \pm 2.21$ & $19.02 \pm 0.26$ & $0.39 \pm 0.01$ \\
\hline Mixed-BCE & $66.23 \pm 1.92$ & $73.19 \pm 1.56^{*}$ & $53.56 \pm 2.24$ & $18.47 \pm 0.40$ & $0.42 \pm 0.00$ \\
\hline Mono-BDE & $47.80 \pm 6.29$ & $67.78 \pm 2.06$ & $51.32 \pm 1.77$ & $19.56 \pm 0.42$ & $0.40 \pm 0.01$ \\
\hline Mixed-BDE & $65.19 \pm 1.55$ & $74.81 \pm 1.20$ & $63.49 \pm 1.33^{* *}$ & $20.93 \pm 0.25$ & $0.46 \pm 0.01 *$ \\
\hline Mono-ABDE & $50.32 \pm 4.85$ & $67.82 \pm 1.53$ & $53.46 \pm 1.79$ & $19.88 \pm 0.38$ & $0.38 \pm 0.01$ \\
\hline Mixed-ABDE & $57.58 \pm 3.06$ & $77.56 \pm 0.59 * *$ & $62.60 \pm 0.94 *$ & $21.23 \pm 0.06$ & $0.43 \pm 0.03$ \\
\hline Mono-BCDE & $52.39 \pm 5.23$ & $67.16 \pm 1.59$ & $53.22 \pm 1.65$ & $19.51 \pm 0.32 *$ & $0.40 \pm 0.01$ \\
\hline Mixed-BCDE & $57.04 \pm 1.81$ & $70.40 \pm 1.40$ & $53.64 \pm 1.66$ & $17.94 \pm 0.60$ & $0.39 \pm 0.00$ \\
\hline Mono-ABCDE & $53.49 \pm 4.21$ & $67.32 \pm 1.27$ & $54.55 \pm 1.54$ & $19.78 \pm 0.31 * *$ & $0.39 \pm 0.01$ \\
\hline Mixed-ABCDE & $55.11 \pm 1.17$ & $69.72 \pm 2.16$ & $56.38 \pm 0.67$ & $17.49 \pm 0.20$ & $0.45 \pm 0.01 *$ \\
\hline \multicolumn{6}{|l|}{ Paired t-test } \\
\hline Mono-cropping & $50.77 \pm 1.33$ & $66.26 \pm 0.59$ & $52.95 \pm 0.69$ & $19.68 \pm 0.17$ & $0.39 \pm 0.00$ \\
\hline Mixed-cropping & $60.68 \pm 1.39 * *$ & $71.91 \pm 1.15^{* *}$ & $57.35 \pm 1.52 *$ & $19.53 \pm 0.60$ & $0.43 \pm 0.01 * *$ \\
\hline
\end{tabular}


Table 2

\begin{tabular}{|c|c|c|c|c|c|}
\hline Treatments & $\begin{array}{l}\text { The number } \\
\text { of spikelet } \\
\text { per panicle }\end{array}$ & $\begin{array}{l}\text { Seed-setting } \\
\text { rate }(\%)\end{array}$ & $\begin{array}{l}\text { Grain weight (g } \\
\text { per pot) }\end{array}$ & $\begin{array}{l}\text { 1000-grain } \\
\text {-weight(g) }\end{array}$ & Harvest index \\
\hline \multicolumn{6}{|l|}{ Independent $t$-test } \\
\hline Mono-AB & $60.26 \pm 3.39$ & $72.47 \pm 0.95$ & $62.56 \pm 1.00$ & $21.41 \pm 0.65$ & $0.44 \pm 0.00$ \\
\hline Mixed-AB & $63.06 \pm 1.47$ & $74.81 \pm 0.81$ & $65.60 \pm 0.12$ & $22.16 \pm 0.92$ & $0.46 \pm 0.01 *$ \\
\hline Mono-BC & $60.69 \pm 3.60$ & $72.09 \pm 0.83$ & $62.61 \pm 0.92$ & $21.36 \pm 0.64$ & $0.44 \pm 0.01$ \\
\hline Mixed-BC & $65.18 \pm 0.72$ & $79.98 \pm 1.10^{* *}$ & $72.43 \pm 1.62 * *$ & $22.55 \pm 0.30$ & $0.46 \pm 0.01 *$ \\
\hline Mono-BE & $61.17 \pm 3.76$ & $73.33 \pm 1.33$ & $61.71 \pm 1.84$ & $21.07 \pm 0.73$ & $0.42 \pm 0.02$ \\
\hline Mixed-BE & $66.93 \pm 1.20$ & $72.41 \pm 0.99$ & $60.55 \pm 2.18$ & $22.18 \pm 0.74$ & $0.44 \pm 0.01$ \\
\hline Mono-ABD & $59.71 \pm 2.25$ & $73.00 \pm 0.69$ & $63.04 \pm 0.73$ & $21.64 \pm 0.46$ & $0.43 \pm 0.00$ \\
\hline Mixed-ABD & $66.17 \pm 1.88$ & $76.32 \pm 0.81 *$ & $62.37 \pm 1.07$ & $20.80 \pm 0.34$ & $0.45 \pm 0.01$ \\
\hline Mono-ACD & $64.86 \pm 1.75$ & $74.06 \pm 0.36$ & $63.12 \pm 0.55$ & $22.18 \pm 0.22$ & $0.44 \pm 0.01$ \\
\hline Mixed-ACD & $63.57 \pm 0.55$ & $76.19 \pm 0.54 *$ & $66.73 \pm 1.10^{* *}$ & $22.68 \pm 0.38$ & $0.47 \pm 0.00 *$ \\
\hline Mono-BCE & $63.58 \pm 2.75$ & $73.45 \pm 0.89$ & $62.05 \pm 1.23$ & $21.43 \pm 0.52$ & $0.43 \pm 0.01$ \\
\hline Mixed-BCE & $63.43 \pm 0.37$ & $76.77 \pm 0.49$ & $65.67 \pm 0.80$ & $23.39 \pm 0.69$ & $0.45 \pm 0.01$ \\
\hline Mono-BDE & $60.32 \pm 2.51$ & $73.58 \pm 0.89$ & $62.47 \pm 1.26$ & $21.42 \pm 0.53$ & $0.42 \pm 0.01$ \\
\hline Mixed-BDE & $68.73 \pm 1.77$ & $79.10 \pm 1.94 *$ & $67.29 \pm 1.01$ & $23.69 \pm 0.68^{*}$ & $0.52 \pm 0.03 * *$ \\
\hline Mono-ABDE & $62.12 \pm 2.10$ & $73.79 \pm 0.68$ & $62.51 \pm 0.97$ & $21.63 \pm 0.41$ & $0.42 \pm 0.01$ \\
\hline Mixed-ABDE & $68.60 \pm 0.68$ & $78.69 \pm 1.54^{* *}$ & $67.83 \pm 0.97 *$ & $21.27 \pm 0.19$ & $0.49 \pm 0.01 * *$ \\
\hline Mono-BCDE & $62.34 \pm 2.16$ & $73.60 \pm 0.68$ & $62.53 \pm 0.95$ & $21.60 \pm 0.41$ & $0.42 \pm 0.01$ \\
\hline Mixed-BCDE & $66.34 \pm 0.95$ & $78.53 \pm 1.37 * *$ & $64.32 \pm 0.80$ & $22.98 \pm 0.23$ & $0.45 \pm 0.00$ \\
\hline Mono-ABCDE & $63.38 \pm 1.82$ & $73.77 \pm 0.55$ & $62.56 \pm 0.79$ & $21.73 \pm 0.34$ & $0.43 \pm 0.01$ \\
\hline Mixed-ABCDE & $62.14 \pm 1.03$ & $72.64 \pm 0.96$ & $61.25 \pm 0.77$ & $21.30 \pm 0.70$ & $0.42 \pm 0.01$ \\
\hline \multicolumn{6}{|l|}{ Paired t-test } \\
\hline Mono-cropping & $61.84 \pm 0.54$ & $73.31 \pm 0.20$ & $62.52 \pm 0.13$ & $21.55 \pm 0.09$ & $0.43 \pm 0.00$ \\
\hline Mixed-cropping & $65.41 \pm 0.73 * *$ & $76.54 \pm 0.83 * *$ & $65.40 \pm 1.12 *$ & $22.30 \pm 0.30 *$ & $0.46 \pm 0.01 * *$ \\
\hline
\end{tabular}


$5 \quad$ Table 3

\begin{tabular}{|c|c|c|c|c|c|c|c|c|}
\hline Treatment & $\begin{array}{c}\text { Brown rice } \\
\text { rate }(\%)\end{array}$ & $\begin{array}{c}\text { Milled rice } \\
\text { rate }(\%)\end{array}$ & $\begin{array}{l}\text { Whole milled } \\
\text { rice rate } \\
(\%)\end{array}$ & $\begin{array}{l}\text { Amylose } \\
\text { content (\%) }\end{array}$ & $\begin{array}{l}\text { Protein } \\
\text { content (\%) }\end{array}$ & Length/width & $\begin{array}{l}\text { Chalky rice rate } \\
(\%)\end{array}$ & $\begin{array}{l}\text { Chalkiness } \\
\text { degree }(\%)\end{array}$ \\
\hline \multicolumn{9}{|l|}{ Independent t-test } \\
\hline Mono-AB & $80.04 \pm 0.34$ & $69.87 \pm 0.92$ & $64.79 \pm 1.56$ & $22.97 \pm 1.52$ & $8.55 \pm 0.26$ & $2.91 \pm 0.03 *$ & $21.18 \pm 2.81$ & $7.07 \pm 0.48^{*}$ \\
\hline Mixed-AB & $81.38 \pm 0.76$ & $71.16 \pm 1.71$ & $63.28 \pm 1.05$ & $23.70 \pm 0.47$ & $8.57 \pm 0.64$ & $2.75 \pm 0.01$ & $12.35 \pm 0.55$ & $4.84 \pm 0.48$ \\
\hline Mono-BC & $80.35 \pm 0.41$ & $69.91 \pm 0.93$ & $63.37 \pm 1.04$ & $21.68 \pm 2.16$ & $8.57 \pm 0.31$ & $2.86 \pm 0.04$ & $22.18 \pm 2.43^{*}$ & $6.75 \pm 0.60$ \\
\hline Mixed-BC & $80.88 \pm 0.43$ & $70.34 \pm 1.16$ & $68.21 \pm 1.45^{*}$ & $22.47 \pm 0.29$ & $9.35 \pm 0.48$ & $2.90 \pm 0.07$ & $12.44 \pm 0.82$ & $5.02 \pm 0.52$ \\
\hline Mono-BE & $79.83 \pm 0.53$ & $67.91 \pm 1.14$ & $59.98 \pm 1.63$ & $23.22 \pm 1.60$ & $8.38 \pm 0.30$ & $2.87 \pm 0.04$ & $21.05 \pm 2.85$ & $6.99 \pm 0.51^{*}$ \\
\hline Mixed-BE & $80.39 \pm 0.82$ & $68.47 \pm 0.71$ & $60.96 \pm 1.97$ & $23.99 \pm 0.76$ & $7.81 \pm 0.24$ & $2.78 \pm 0.07$ & $13.30 \pm 0.55$ & $4.85 \pm 0.11$ \\
\hline Mono-ABD & $79.72 \pm 0.30$ & $69.77 \pm 0.61$ & $64.70 \pm 1.01$ & $21.97 \pm 1.26$ & $8.72 \pm 0.21$ & $2.92 \pm 0.02$ & $18.01 \pm 2.41$ & $6.40 \pm 0.47$ \\
\hline Mixed-ABD & $78.84 \pm 0.82$ & $69.89 \pm 0.96$ & $61.75 \pm 0.57$ & $19.89 \pm 1.06$ & $8.37 \pm 0.83$ & $2.94 \pm 0.08$ & $12.29 \pm 0.26$ & $4.87 \pm 0.17$ \\
\hline Mono-ACD & $79.68 \pm 0.30$ & $70.28 \pm 0.36$ & $65.99 \pm 0.69$ & $18.94 \pm 0.89$ & $8.73 \pm 0.19$ & $2.90 \pm 0.03$ & $14.56 \pm 0.94 * *$ & $5.55 \pm 0.20^{* *}$ \\
\hline Mixed-ACD & $82.2 \pm 0.17 * *$ & $71.25 \pm 1.74$ & $69.36 \pm 1.59^{*}$ & $20.75 \pm 0.83$ & $10.06 \pm 0.18^{* *}$ & $3.02 \pm 0.05$ & $6.67 \pm 0.81$ & $1.50 \pm 0.70$ \\
\hline Mono-BCE & $79.99 \pm 0.40$ & $68.83 \pm 0.89$ & $61.76 \pm 1.41$ & $21.19 \pm 1.51$ & $8.45 \pm 0.24$ & $2.86 \pm 0.03$ & $19.70 \pm 2.01$ & $6.49 \pm 0.42 *$ \\
\hline Mixed-BCE & $78.43 \pm 0.48$ & $67.53 \pm 0.12$ & $64.76 \pm 0.53$ & $18.39 \pm 0.69$ & $9.74 \pm 0.15^{*}$ & $2.77 \pm 0.05$ & $13.93 \pm 1.14$ & $4.45 \pm 0.35$ \\
\hline Mono-BDE & $79.57 \pm 0.39$ & $68.46 \pm 0.80$ & $61.49 \pm 1.30$ & $22.14 \pm 1.31$ & $8.61 \pm 0.24$ & $2.89 \pm 0.03$ & $17.92 \pm 2.42$ & $6.35 \pm 0.47$ \\
\hline Mixed-BDE & $80.52 \pm 1.07$ & $70.56 \pm 1.79$ & $68.05 \pm 1.38^{*}$ & $19.49 \pm 0.42$ & $9.07 \pm 0.32$ & $3.03 \pm 0.05^{*}$ & $10.71 \pm 0.30$ & $4.61 \pm 0.21$ \\
\hline Mono-ABDE & $79.60 \pm 0.29$ & $69.00 \pm 0.67$ & $63.16 \pm 1.30$ & $21.53 \pm 1.03$ & $8.59 \pm 0.19$ & $2.90 \pm 0.02$ & $17.19 \pm 1.84$ & $6.29 \pm 0.35$ \\
\hline Mixed-ABDE & $80.48 \pm 0.32$ & $69.94 \pm 1.47$ & $67.48 \pm 1.22$ & $21.65 \pm 0.87$ & $9.13 \pm 0.34$ & $2.96 \pm 0.05$ & $12.33 \pm 0.43$ & $5.04 \pm 0.08$ \\
\hline Mono-BCDE & $79.76 \pm 0.33$ & $69.02 \pm 0.67$ & $62.45 \pm 1.11$ & $20.89 \pm 1.21$ & $8.60 \pm 0.20$ & $2.88 \pm 0.03$ & $17.69 \pm 1.82$ & $6.13 \pm 0.37^{*}$ \\
\hline Mixed-BCDE & $80.56 \pm 0.73$ & $68.04 \pm 1.96$ & $61.57 \pm 0.32$ & $21.31 \pm 1.11$ & $9.24 \pm 0.97$ & $2.95 \pm 0.06$ & $14.99 \pm 1.09$ & $3.81 \pm 0.61$ \\
\hline Mono-ABCDE & $79.74 \pm 0.27$ & $69.33 \pm 0.57$ & $63.59 \pm 1.08$ & $20.65 \pm 0.97$ & $8.59 \pm 0.17$ & $2.89 \pm 0.02$ & $17.15 \pm 1.48$ & $6.13 \pm 0.29$ \\
\hline Mixed-ABCDE & $80.05 \pm 0.62$ & $67.64 \pm 1.75$ & $62.09 \pm 0.55$ & $21.68 \pm 1.13$ & $8.83 \pm 0.36$ & $2.83 \pm 0.04$ & $15.78 \pm 1.15$ & $5.78 \pm 0.91$ \\
\hline \multicolumn{9}{|l|}{ Paired t-test } \\
\hline Mono-cropping & $79.83 \pm 0.07$ & $69.24 \pm 0.23$ & $63.13 \pm 0.56$ & $21.52 \pm 0.39$ & $8.58 \pm 0.03$ & $2.89 \pm 0.01$ & $18.66 \pm 0.74 * *$ & $6.41 \pm 0.14 * *$ \\
\hline Mixed-cropping & $80.27 \pm 0.42$ & $69.48 \pm 0.45$ & $64.75 \pm 1.02$ & $21.33 \pm 0.56$ & $9.02 \pm 0.21$ & $2.89 \pm 0.03$ & $12.48 \pm 0.80$ & $4.48 \pm 0.37$ \\
\hline
\end{tabular}




\section{$7 \quad$ Table 4}

\begin{tabular}{|c|c|c|c|c|c|c|c|c|}
\hline Treatment & $\begin{array}{c}\text { Brown rice } \\
\text { rate }(\%)\end{array}$ & $\begin{array}{l}\text { Milled rice } \\
\text { rate }(\%)\end{array}$ & $\begin{array}{l}\text { Whole milled } \\
\text { rice rate }(\%)\end{array}$ & $\begin{array}{l}\text { Amylose } \\
\text { content (\%) }\end{array}$ & $\begin{array}{l}\text { Protein } \\
\text { content (\%) }\end{array}$ & Length/width & $\begin{array}{l}\text { Chalky rice } \\
\text { rate }(\%)\end{array}$ & $\begin{array}{l}\text { Chalkiness } \\
\text { degree (\%) }\end{array}$ \\
\hline \multicolumn{9}{|l|}{ Independent t-test } \\
\hline Mono-AB & $76.87 \pm 0.24$ & $67.73 \pm 0.24$ & $60.60 \pm 0.38$ & $20.40 \pm 2.42$ & $7.67 \pm 0.46$ & $2.94 \pm 0.02$ & $13.38 \pm 2.21$ & $5.43 \pm 0.59 *$ \\
\hline Mixed-AB & $74.85 \pm 1.53$ & $67.48 \pm 1.70$ & $62.06 \pm 0.87$ & $22.91 \pm 0.98$ & $8.10 \pm 0.05$ & $3.10 \pm 0.06^{*}$ & $8.56 \pm 0.19$ & $3.33 \pm 0.36$ \\
\hline Mono-BC & $76.31 \pm 0.22$ & $67.90 \pm 0.27$ & $60.94 \pm 0.25^{*}$ & $23.77 \pm 0.91 *$ & $7.86 \pm 0.51$ & $3.00 \pm 0.02$ & $13.46 \pm 2.14$ & $5.01 \pm 0.60$ \\
\hline Mixed-BC & $76.45 \pm 1.33$ & $71.61 \pm 0.00 * *$ & $59.74 \pm 0.37$ & $20.53 \pm 0.32$ & $8.16 \pm 0.33$ & $3.02 \pm 0.09$ & $7.67 \pm 0.33$ & $3.73 \pm 0.33$ \\
\hline Mono-BE & $76.03 \pm 0.33$ & $67.42 \pm 0.36$ & $60.57 \pm 0.33$ & $23.39 \pm 1.11$ & $7.67 \pm 0.47$ & $2.95 \pm 0.02$ & $13.25 \pm 2.20$ & $6.18 \pm 0.24$ \\
\hline Mixed-BE & $77.52 \pm 0.88$ & $69.36 \pm 1.92$ & $63.48 \pm 1.51^{*}$ & $22.69 \pm 0.63$ & $8.17 \pm 0.06$ & $3.02 \pm 0.04$ & $7.08 \pm 0.38$ & $5.27 \pm 0.59$ \\
\hline Mono-ABD & $76.64 \pm 0.22$ & $67.52 \pm 0.26$ & $60.60 \pm 0.28^{*}$ & $21.11 \pm 1.62$ & $7.82 \pm 0.35$ & $2.96 \pm 0.02$ & $11.76 \pm 1.65$ & $5.30 \pm 0.40^{*}$ \\
\hline Mixed-ABD & $75.11 \pm 2.40$ & $69.12 \pm 0.60^{*}$ & $58.87 \pm 1.05$ & $25.02 \pm 0.64$ & $8.45 \pm 0.41$ & $2.99 \pm 0.01$ & $8.78 \pm 0.82$ & $3.51 \pm 0.53$ \\
\hline Mono-ACD & $76.57 \pm 0.26$ & $67.43 \pm 0.24$ & $60.40 \pm 0.26$ & $19.78 \pm 1.23$ & $7.95 \pm 0.25$ & $2.97 \pm 0.02$ & $9.16 \pm 0.50 * *$ & $4.44 \pm 0.36^{* *}$ \\
\hline Mixed-ACD & $78.53 \pm 0.58 * *$ & $69.45 \pm 0.17 * *$ & $64.00 \pm 0.27 * *$ & $18.14 \pm 0.27$ & $8.24 \pm 0.18$ & $3.13 \pm 0.01 * *$ & $4.19 \pm 0.95$ & $1.41 \pm 0.49$ \\
\hline Mono-BCE & $76.09 \pm 0.24$ & $67.53 \pm 0.26$ & $60.60 \pm 0.25$ & $22.85 \pm 0.77 *$ & $7.80 \pm 0.35$ & $2.97 \pm 0.02$ & $12.02 \pm 1.56^{*}$ & $5.36 \pm 0.44 * *$ \\
\hline Mixed-BCE & $78.09 \pm 0.76^{* *}$ & $67.57 \pm 1.95$ & $61.96 \pm 1.03$ & $18.56 \pm 0.27$ & $7.51 \pm 0.23$ & $3.07 \pm 0.09$ & $5.63 \pm 0.95$ & $1.46 \pm 0.28$ \\
\hline Mono-BDE & $76.08 \pm 0.24$ & $67.32 \pm 0.30$ & $60.58 \pm 0.25$ & $23.10 \pm 0.76$ & $7.82 \pm 0.36$ & $2.96 \pm 0.02$ & $11.67 \pm 1.64 *$ & $5.80 \pm 0.27 * *$ \\
\hline Mixed-BDE & $78.83 \pm 1.01 * *$ & $70.20 \pm 0.60 * *$ & $63.58 \pm 0.46^{* *}$ & $24.12 \pm 0.58$ & $8.55 \pm 0.29$ & $3.08 \pm 0.02 * *$ & $5.10 \pm 0.17$ & $2.39 \pm 0.14$ \\
\hline Mono-ABDE & $76.39 \pm 0.24$ & $67.34 \pm 0.22$ & $60.42 \pm 0.23$ & $21.08 \pm 1.20$ & $7.79 \pm 0.27$ & $2.95 \pm 0.01$ & $11.10 \pm 1.27 *$ & $5.49 \pm 0.33 * *$ \\
\hline Mixed-ABDE & $78.79 \pm 0.24 * *$ & $69.59 \pm 0.37 * *$ & $62.15 \pm 0.89 *$ & $23.36 \pm 0.56$ & $8.71 \pm 0.18$ & $3.05 \pm 0.02 * *$ & $5.32 \pm 0.98$ & $1.76 \pm 0.32$ \\
\hline Mono-BCDE & $76.11 \pm 0.20$ & $67.43 \pm 0.24$ & $60.59 \pm 0.21$ & $22.77 \pm 0.59$ & $7.88 \pm 0.29$ & $2.98 \pm 0.01$ & $11.14 \pm 1.25$ & $5.28 \pm 0.34 * *$ \\
\hline Mixed-BCDE & $77.66 \pm 1.12 *$ & $66.55 \pm 1.71$ & $60.96 \pm 0.87$ & $25.26 \pm 0.25$ & $8.36 \pm 0.27$ & $2.97 \pm 0.03$ & $8.41 \pm 0.05$ & $1.95 \pm 0.78$ \\
\hline Mono-ABCDE & $76.35 \pm 0.21$ & $67.42 \pm 0.19$ & $60.47 \pm 0.20$ & $21.22 \pm 0.96$ & $7.84 \pm 0.23$ & $2.96 \pm 0.01$ & $10.80 \pm 1.03$ & $5.14 \pm 0.32 *$ \\
\hline Mixed-ABCDE & $75.73 \pm 0.60$ & $68.02 \pm 1.99$ & $59.79 \pm 0.40$ & $23.80 \pm 0.93$ & $8.31 \pm 0.01$ & $2.97 \pm 0.03$ & $5.85 \pm 0.54$ & $2.90 \pm 0.88$ \\
\hline \multicolumn{9}{|l|}{ Paired t-test } \\
\hline Mono-cropping & $76.34 \pm 0.09$ & $67.50 \pm 0.06$ & $60.58 \pm 0.05$ & $21.95 \pm 0.44$ & $7.81 \pm 0.13$ & $2.96 \pm 0.00$ & $\begin{array}{l}11.77 \pm 0.43 * \\
*\end{array}$ & $5.34 \pm 0.15^{* *}$ \\
\hline Mixed-cropping & $77.15 \pm 0.48$ & $68.89 \pm 0.47$ & $61.66 \pm 0.56$ & $22.44 \pm 0.80$ & $8.25 \pm 0.20$ & $3.04 \pm 0.02$ & $6.66 \pm 0.52$ & $2.77 \pm 0.39$ \\
\hline
\end{tabular}




\section{$9 \quad$ Table 5}

\begin{tabular}{|c|c|c|c|c|}
\hline \multirow{2}{*}{ Treatments } & \multicolumn{2}{|c|}{ Early growing season } & \multicolumn{2}{|c|}{ Late growing season } \\
\hline & SPAD index & $\mathrm{Pn}$ & SPAD index & Pn \\
\hline DW & $0.85^{* *}$ & $0.68 * *$ & $0.75^{* *}$ & 0.44 \\
\hline Spikelet per Panicle & 0.34 & -0.02 & 0.18 & 0.48 \\
\hline Seed-setting rate & $0.58^{*}$ & $0.59 *$ & $0.77 * *$ & $0.75 * *$ \\
\hline Grain weight per pot & $0.74 * *$ & $0.54 *$ & $0.88 * *$ & $0.60 *$ \\
\hline 1000-grain-weight & $0.65^{* *}$ & 0.29 & 0.45 & $0.58 *$ \\
\hline Harvest index & $0.65 * *$ & $0.78 * *$ & $0.73 * *$ & $0.64 *$ \\
\hline Brown rice rate & 0.28 & $0.56^{*}$ & $0.55^{*}$ & $0.64 *$ \\
\hline Milled rice rate & $0.52 *$ & 0.31 & 0.37 & 0.33 \\
\hline Whole milled rice rate & $0.67 * *$ & $0.56^{*}$ & 0.37 & 0.25 \\
\hline Amylose content & -0.29 & 0.09 & -0.11 & -0.23 \\
\hline Protein content & $0.53 *$ & $0.66^{* *}$ & 0.40 & 0.20 \\
\hline Length/width & 0.46 & 0.32 & $0.62 *$ & 0.21 \\
\hline Chalky rice rate & $-0.76^{* *}$ & $-0.62 * *$ & $-0.64 *$ & -0.49 \\
\hline Chalkiness degree & -0.40 & $-0.63 *$ & $-0.65 * *$ & -0.38 \\
\hline
\end{tabular}

10 Note: *and ** represent significance at $\mathrm{P}<0.05$ and 0.01 levels, respectively. 
bioRxiv preprint doi: https://doi.org/10.1101/317545; this version posted May 8, 2018. The copyright holder for this preprint (which was not certified by peer review) is the author/funder, who has granted bioRxiv a license to display the preprint in perpetuity. It is made available under aCC-BY 4.0 International license.

Fig. 1
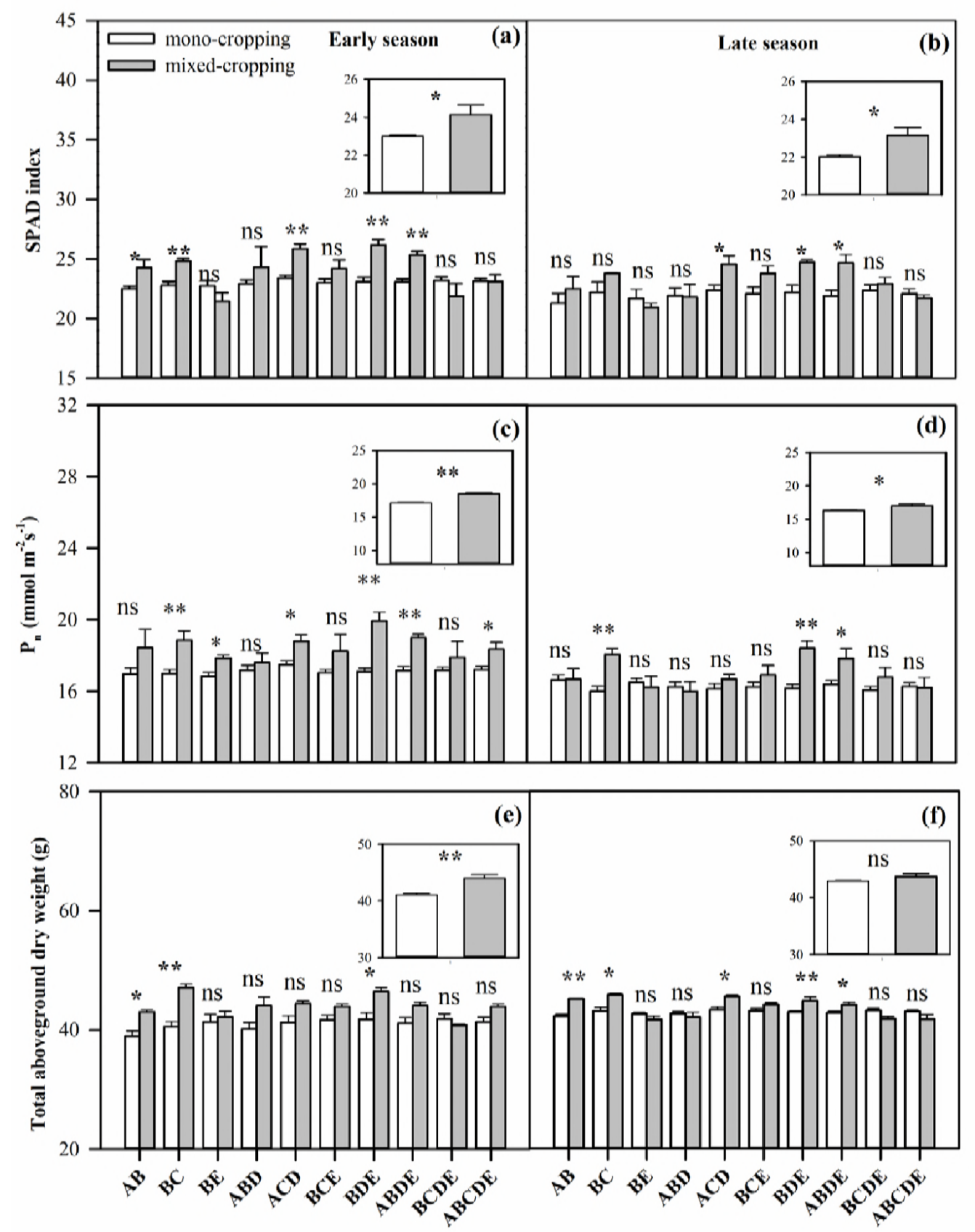


\section{S1 Table S1}

\begin{tabular}{|c|c|c|c|c|c|c|c|c|c|c|c|}
\hline Varieties & Period (d) & Height (cm) & $\begin{array}{l}\text { Spikelet per } \\
\text { panicle }\end{array}$ & $\begin{array}{l}\text { Seed setting } \\
\text { rate }(\%)\end{array}$ & $\begin{array}{l}\text { 1000-grain } \\
\text { weight }(\mathrm{g})\end{array}$ & $\begin{array}{l}\text { Brown rice } \\
\text { rate }(\%)\end{array}$ & $\begin{array}{l}\text { Chalky } \\
\text { rice }(\%)\end{array}$ & $\begin{array}{l}\text { Chalkiness } \\
\text { degree }(\%)\end{array}$ & $\begin{array}{l}\text { Amylose } \\
\text { content (\%) }\end{array}$ & $\begin{array}{l}\text { Length/ } \\
\text { width }\end{array}$ & $\begin{array}{l}\text { Yield } \\
\left(\mathrm{t} \mathrm{hm}^{2}\right)\end{array}$ \\
\hline Yuenongsimiao (A) & $111 \sim 113$ & $97.0 \sim 97.9$ & $122 \sim 124$ & $87.1 \sim 88.0$ & $22.0 \sim 22.6$ & $71.8 \sim 73.0$ & $3 \sim 6$ & $0.5 \sim 0.9$ & $17.3 \sim 18.2$ & $3.3 \sim 3.5$ & 6.57 \\
\hline Yuxiangyouzhan (B) & $126 \sim 128$ & $105.6 \sim 106.4$ & 133.8 & $81.6 \sim 86.0$ & 22.6 & $46.3 \sim 47.0$ & 13 & $2.6 \sim 8.7$ & $3.7 \sim 26.3$ & / & 6.95 \\
\hline Huangguangyouzhan (C) & $128 \sim 132$ & $107.7 \sim 110.1$ & $133 \sim 144$ & $84.9 \sim 87.2$ & $24.5 \sim 24.6$ & 44.0 & $8 \sim 11$ & $1.0 \sim 2.5$ & $13.7 \sim 15.9$ & 3.1 & 7.62 \\
\hline Huanghuazhan (D) & $129 \sim 131$ & $93.8 \sim 102.8$ & $118.3 \sim 123$ & $80.5 \sim 86.8$ & $22.2 \sim 23.1$ & $40.0 \sim 55.2$ & $4 \sim 6$ & $0.6 \sim 3.2$ & $13.8 \sim 14.0$ & / & 7.20 \\
\hline Huahang 31 (E) & $110 \sim 111$ & $109.5 \sim 110.6$ & $132.1 \sim 132$ & $83.5 \sim 85.8$ & $22 \sim 22.3$ & $70.4 \sim 72.5$ & $4 \sim 18$ & $0.8 \sim 6.9$ & $16.2 \sim 16.5$ & / & 6.31 \\
\hline
\end{tabular}

15 